\title{
International research activities and harmonious development of student's personality
}

\author{
Elena Makarova ${ }^{1, *}$, and Hilola Ochilova ${ }^{2}$ \\ ${ }^{1}$ Ural State University of Economics, 620144 Yekaterinburg, Russia \\ ${ }^{2}$ Tashkent State University of Economics, 100066 Tashkent, Uzbekistan
}

\begin{abstract}
The article discusses the role of universities in developing student's harmonious personality through their involvement in international educational and scientific events. Experiences in organizing and holding international Eurasian Economic Youth Forum are described, benefits of students' presenting research papers on international platforms are considered. The analyses of international cooperation between Tashkent State University of Economics and Russian higher educational institutions are provided. Applying theoretical and qualitative research methods allowed to prove the effectiveness of scientific extracurricular activities for improving students' professional skills, realizing their creative potential and fostering their personality growth. Getting students to participate in international educational and research projects promote effective implementing principles of sustainable development in education. Perspectives on international students' research experiences are outlined.
\end{abstract}

\section{Introduction}

Achieving sustainable development goals demands introducing new measures which can support students of higher educational establishments to harmoniously develop both professionally and personally. Harmonious personality development can be achieved by means of students' participation in various offline and online educational activities, including extracurricular ones. International extracurricular educational and scientific projects provide university students with opportunities to facilitate their global awareness.

The issue of harmonious development of students' personality in the context of sustainable development is one of the most relevant. Sustainable functioning of modern economic systems, accompanied by the introduction of new technologies and changing requirements of employers, makes training of highly qualified personnel a priority task. At present "the main goal of professional training is to activate the potential and abilities of students, in which they are able to creatively express themselves, assert themselves and realize themselves" [1]. Without providing young people with opportunities and conditions for their harmonious development this goal is hardly achievable. Higher education

\footnotetext{
*Corresponding author: makarovayn@mail.ru
} 
professionals have recently been involved in scientific discussions and debates on the role of education in personality development $[2,3]$.

The review of literature shows that the trends and forms of classroom and extracurricular activities aimed at the fulfilment of universities' mission to improve students' professional social and personal competencies are various. This mission can be successfully carried out through engagement of students in a variety of educational and research projects. A good example of young people's involvement which gives them an opportunity to play a significant role in society is volunteering. Widespread introduction of volunteering as a form of educational activity for students of higher educational institutions contributes to their gaining experience necessary for their future professional activities. In addition to professional knowledge and skills, participation in volunteering projects, according to researchers, can contribute to the harmonious development of a student's personality [4, 5]. Abilities of establishing a sustainable lifestyle and creating well-balanced personal and working environments is an integral characteristic of a harmoniously developed personality. These abilities can be improved by students' involvement in activities which allow to apply academic knowledge in the context of a real world. In the recent paper by Auditi Pramanik, implementing of a project based-learning method in students' analysis of Rabindranath Tagore's writings is described as a successful example of the activity, which enforces development of learner's harmonious personality [6]. The literature on sustainable development issues proves the existence of close links between sustainability and creativity [7]. Previous research has demonstrated that creativity remains an integral component of a harmoniously developed personality [8] and is considered a necessary resource for fulfilling various tasks and solving numerous problems. Being creative is particularly important for university graduates to be prepared to work in the conditions of the new economic reality which is accompanied by the challenges of digital transformation. The most interesting approach to improving students' research skills which are of significance for harmonious development of personality, has been proposed by E. Bureeva. Participation in project "Sovremennik" ("Contemporary"), conducted in Kazan State University of Architecture and Civil Engineering, is focused on the formation of students historical thinking. It was observed that students' collecting and organizing information in forms of reports and scientific articles arouse their interest to history and respect to their country, city and community [9]. Alongside with one subject-related activities, there can also be scientific interdisciplinary projects. They are aimed at developing students' ability to effectively cope with a whole complex of multidisciplinary problems which young people can face in their future professional life, including organizational and managerial ones [10].

A challenging problem which remains open, is developing university graduates' readiness to work in international environment. Establishment of educational and scientific ties at the international level is an integral characteristic of the world education system. The process of integration of educational organizations of all levels into international educational space is increasing [11]. The entry of universities into the international educational environment can be carried out through attracting students to participate in international educational projects [12]. It can be observed that in order to get students ready for their future international professional activities, an increasing number of higher educational institutions are introducing international students' educational and scientific projects.

\section{Materials and methods}

The paper considers university students' involvement in international educational and scientific activities to foster their professional and personality development. Theoretical and 
qualitative research methods such as observation and data content and narrative analysis are used for examining students' experiences in events held in different higher educational institutions of the Russian Federation on the improvement of their knowledge and skills. The study first discusses the experience of Ural State University of Economics (Yekaterinburg, Russia) in organizing a major international event "Eurasian Economic Youth Forum". Another objective is to examine involvement of the students of Tashkent State University of Economics (Tashkent, Uzbekistan) in international projects and activities held in different higher educational establishments of the Russian Federation. Students' experiences in conducting research and presenting results on the platforms of international conferences are analysed and described. The paper presents practical advantages of such activities for promoting principles of education for sustainable development.

\section{Results and discussion}

\subsection{Eurasian Economic Youth Forum: challenging opportunities and students' experiences}

One of the events, participation in which contributes to the harmonious development of student's personality and improves both professional and soft skills, is the International Youth Movement "Eurasian Economic Youth Forum" annually held at the Ural State University of Economics (Yekaterinburg, Russia). This international project is a good example of partnership not only between higher educational institutions of many countries but effective cooperation of universities with research centers, business structures and industrial companies. In April 2021 Ural State Economic University hosted XI Eurasian Economic Youth Forum for the eleventh time. Each academic year the forum organizers select a new topic in accordance with the latest global and national economic trends. XI Forum was held on the topic "Russia and the Regions of the World: Embodiment of Ideas and the Economy of Opportunities". The following congresses, each covering a certain sector of economy, worked within the Forum:

- Congress of Financiers, promoting young people's understanding of current financial challenges and problems, their anticipating and solving;

- Congress of Innovators, allowing students consider new technologies used in business management;

- Congress of Service Technologies, contributing to the discussion of practical application of scientific research methods to service industry;

- Congress of Strategists, providing university students with the opportunity to share ideas and present projects on the challenges of the digitalization of the economy and opportunities for enterprises to implement innovation strategies;

- Congress of Economists, serving as an international platform for meaningful analysis of existing economic programs and developing ideas for overcoming economic crises and stabilizing economic processes.

The process of project preparation and its presenting in front of the board of experts enables university students to reveal their creative potential, fosters development of student's motivation to learn, strengthens their research skills. Participating in discussions and debates on the main trends of global world economy promotes students' developing such universal competencies as the ability to conduct a constructive dialogue and defend their point of view. Neither professional nor harmonious personal development is possible without the ability of a university graduate to convince a partner and effectively work in a team. The Eurasian Economic Youth Forum initiates close communication between 
students presenting their individual and team projects with experienced experts, who are representatives of science, business and industry. This enables the transfer of knowledge of experienced professionals to students.

Development of a foreign language communicative competence is accepted as a prerequisite for the formation of a harmonious multicultural personality and is considered a key competence for successful adaptation of youth in the context of globalization. Therefore, the organizers support activities of students in foreign languages. International competition of research projects in English and Spanish "Socio-cultural ties as the basis of trust in economy" is held within the Congress of Economists and is initiated by the Department of Business Foreign Language in cooperation with Máximo Gómez Báez University (Ciego de Ávila, Cuba) and the Department of International Relations of Eurasian National University named after L.N. Gumilyov (Nur-Sultan, Republic of Kazakhstan). The results of the first contest held in 2019 are presented in the paper on universities' collaboration projects [13]. In April 2021 students from Russian and foreign universities, including Tver State University, Ural State Federal University, Tashkent State Economic University, Máximo Gómez Báez University and others presented projects on the crucial economic and social issues, for example, "Cooperation between Russia and China in the Field of Education as a Factor of Strengthening Investment Ties", "Historical and cultural ties as a tool for deepening mutual understanding and developing socioeconomic cooperation", "Doing Business in the Mediterranean: A Comparative Approach to the Entrepreneurial Environment" and others. Students of Tashkent State University of Economics, participating in the forum on-line, presented 2 projects on the development of the travel and tourism industry:" Social tourism as a vital part of the tourism industry" and "Restoring Economic Cooperation and Historical and Cultural Ties along the Great Silk Road". Contest participants considered educational, social and cultural ties between different countries as solid foundation for economic cooperation, discussed perspectives for their establishment and strengthening, emphasized the significance of employees' crosscultural training for their successful adaption to cross-cultural working environment. The students had a unique opportunity to communicate with representatives of different cultures in a foreign language and to develop foreign language communicative and cross-cultural competences. According to the students' responses, this experience has given them a new perspective in their research, a sense of international community and fostered their communication skills.

\subsection{Tashkent State University of Economics: students' engagement in international projects}

In recent years, cooperation between Republic of Uzbekistan and the Russian Federation in various fields has risen to a new level. In 2019 the intergovernmental agreement on the organization and establishment of higher educational institutions' activities between two countries entered into force. In addition, the agreement on the mutual recognition of documents on education, qualifications and scientific degrees awarded in the Russian Federation and Republic of Uzbekistan has been signed. In these conditions universities of both countries seek for opportunities to establish relations, contributing to mutually beneficial partnership.

Cooperation between Tashkent State University of Economics and the Russian International Academy of Tourism started in September 2018. Scientific collaboration of teachers served as the foundation for students' engagement in research and educational projects. The latest event within the frame of this partnership is students and teachers' participation in XI International Scientific and Practical Conference "Foreign Languages in the Educational Space of a Tourist University" held online and hosted by Russian 
International Academy of Tourism in March 2021. Students of the International Tourism Department supervised by the teaching staff of the Department of Tourism and Service took an active part in the plenary meeting and numerous sections, discussing the significance of foreign languages for specialists of travel and tourism industry. The established cooperation between Russian International Academy of Tourism with Vatel Business School (France) offers graduates of Tashkent State University of Economics majoring in the field of tourism, a perspective of participating in a double diploma project with the French partners on the basis of a joint bachelor's training program. Though due to the Covid-19 pandemic this process has been delayed, the project implementation is planned to be completed.

Another example of students' engagement in international activities concerns participation of Tashkent State University of Economics in XI International student scientific conference "Student research in the field of tourism and sports management", organized by Sochi State University. Students from Germany, Uzbekistan, Georgia and many regions of Russia took part in this event, presenting papers on the development of tourism industry. Students of Tashkent State University of Economics made scientific reports, presenting results of research on topical issues of tourism trends in the Republic of Uzbekistan. Within the framework of this project, several events, aimed at meeting sustainable development goals and empowering youth for sustainable future have been planned. Among them Regional Platform of the III International Moscow Academic Economic Forum on the topic "Global transformation of modern society and goals of national development of Russia" and International scientific conference "Olympic heritage and large-scale events: impact on the economy, ecology and socio-cultural spheres of host destinations in the context of digitalization". In November 2021 the international scientific and practical conference "Trends in the development of MICE tourism and the use of foreign experience in Uzbekistan" is planned to be held at Tashkent State University of Economics, organized in cooperation with the staff of the Russian State University of Tourism and Service. Engagement of international experts in the conference work is considered to foster a constructive atmosphere with a perspective of using Russian event tourism experiences in holding international sports competitions in Republic of Uzbekistan.

Positive feedback from the students of Tashkent State University of Economics on their involvement in the activities of Eurasian Economic Youth Forum held in Ekaterinburg, prove their interest to large-scale international events with participation of representatives of different higher educational institutions from different countries.

\section{Conclusion}

Developing and delivering quality education which promotes sustainable lifestyles and sustainable development is included in the list of Priority Areas of the UN Youth Strategy. According to United Nation Youth Strategy 2030, young people should be involved in various activities allowing them to progress, be supported and empowered to achieve their full potential. Harmony in young people's personal and professional lives, which is the goal of any educational process, can be reached through their engagement in various university classroom and extracurricular practices. The findings based on observations of students' experiences in international educational and research projects and analysis of their perception by organizers and participants have shown positive effect of the events on the harmonious professional and personality development of university students. It has been demonstrated that participation in Eurasian Economic Youth Forum helped young people gain relevant knowledge, realize their creative potential and develop professional and universal competencies and skills, contributing to the personality growth. Presenting the results of their research students are given opportunities to share ideas not only with each other, but be engaged in a dialogue with leading economic experts, scientists, managers and 
businessmen. Taking part in the Forum students get access to the results of latest research on the economic, social and cultural national and global issues and challenges as well as have possibilities to discuss ways for their innovative solutions. Aside from gaining knowledge related to economy and pursuing their professional goals, communication with Forum participants from many countries of the world promote students' social interaction skills. Discussions, held during the Forum, strengthen students' collaboration, which in the future can lead to international economic partnerships and cooperation. Intercultural communication on the Forum's platform definitely contributes to the promotion of a culture of peace and better understanding of other nations and their values.

Analyses of participation of the students of Tashkent State University of Economics in international projects held by higher educational establishments of the Russian Federation show that these practices benefit both sides. Exchange of knowledge relevant to the students' field of study can be beneficial for students' career opportunities in the future as doing research they learn to apply theoretical knowledge into practice. Debate activities and students' experiences in international scientific discussions have a motivational effect and foster critical thinking and problem solving which are the key competences in sustainability and harmonious personality development.

Further development of youth international movement through organizing online and offline research events have great potential for introducing ideas and principles of sustainable development to university students.

\section{References}

1. I.V. Kostakova, L.I. Yafyasova, Science Vector of Togliatti State University. Series: Pedagogy, Psychology, 3, 78 (2018)

2. A. Šmeringaiová, ICERI2020 Proc., 13, 3870 (2020)

3. H. Audunsson, T.V. Fridgeirsson, Á. Matthíasdóttir, CDIO Conf. Proc., 16, 325 (2020)

4. O. Tashkinova, O. Rogovska, S. Bulgakova, Int. Sci. J. Univ. and Leadership, 1, 97 (2019)

5. M. Nathanson, S. Rau, E. Jiang, S. Phyllis, AJGP, 29, 130 (2021)

6. A. Pramanik, GDCEI Malaysia-2019 Proc. (2019)

7. D. Štreimikienè, T. Kačerauskas, Sustain. Dev., 28, 1632 (2020)

8. R. Ehtiyar, G. Baser, EJER, 80, 113 (2019)

9. E.V. Bureeva, Baltic Human. J., 10, 43 (2021)

10. S. Barabanova, N. Kraysman, T. Makarov, L. Schurikova, F. Myshko, AISC, 1134, 55 (2020)

11. M.I. Lukyanova, L.A. Saveleva, Modern High Tech., 2, 182 (2021)

12. P. Silva, A. Mesquita, ICERI2019 Proc., 12, 8204 (2019)

13. E. Makarova, J. Wang, E3S Web Conf., 208, 09015 (2020) 